\title{
Differences in the density, sinking rate and biochemical composition of Centropages tenuiremis (Copepoda: Calanoida) subitaneous and diapause eggs
}

\author{
Guizhong Wang ${ }^{1, *}$, Xiaodong Jiang ${ }^{1,2}$, Lisheng Wu ${ }^{1}$, Shaojing Li $^{1}$ \\ ${ }^{1}$ Department of Oceanography, State Key Laboratory of Marine Environmental Science, Xiamen University, \\ 422 Siming South Road, Xiamen 361005, PR China \\ ${ }^{2}$ Polar Research Institute of China, 451 Jinqiao Road, Shanghai 200136, PR China
}

\begin{abstract}
The density, sinking rate and biochemical composition of Centropages tenuiremis subitaneous and diapause eggs were determined in the laboratory. The mean densities of subitaneous and diapause eggs were 1.1176 and $1.1481 \mathrm{~g} \mathrm{~cm}^{-3}$, respectively. Based on Stokes' law, the average sinking rate was $0.0266 \mathrm{~cm} \mathrm{~s}^{-1}$ for subitaneous eggs and $0.0367 \mathrm{~cm} \mathrm{~s}^{-1}$ for diapause eggs. The dry weight, lipid, protein and carbohydrate contents of subitaneous eggs were 117.7, 32.9, 59.1 and

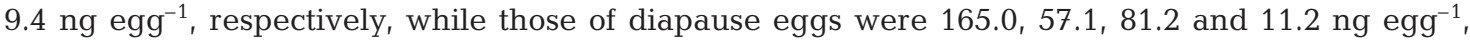
respectively. The levels of aspartic acid, glutamic acid, glycine, methionine, isoleucine, leucine, norleucine, lysine, ammonium chloride, and arginine in diapause eggs of $C$. tenuiremis were significantly higher than in subitaneous eggs. Results of the study showed that there were significant physiological and biochemical differences between subitaneous and diapause eggs of C. tenuiremis.
\end{abstract}

KEY WORDS: Centropages tenuiremis $\cdot$ Difference $\cdot$ Density $\cdot$ Sinking rate $\cdot$ Biochemical composition

\section{INTRODUCTION}

It is well known that many estuarine and coastal planktonic copepods depend on the hatching of benthic resting eggs for recruitment of nauplii to the water column population (Marcus 1984). Copepod resting eggs in the sediment of bays and estuaries can be extremely abundant, which is likely to greatly affect the dynamics of the pelagic community (Boero et al. 1996, Hairston et al. 2000, Bell \& Weithoff, 2003), since benthic resting eggs ensure the persistence of such species and are important agents of local recolonization. Resting eggs could be classified into 2 types: subitaneous and diapause eggs (Grice \& Marcus 1981, Marcus 1996). Subitaneous eggs can normally hatch after spawning, but if they are exposed to unsuitable conditions (e.g. low temperature or oxygen), development is delayed and they become quiescent. Unlike subitaneous eggs, diapause eggs must undergo a refractory phase during which development does not resume, even if conditions are suitable (Grice \& Marcus 1981, Marcus 1996).

Many studies have focused on the outer morphological differences between subitaneous and diapause eggs. Marine calanoid copepods often have spiny diapause eggs, while their subitaneous eggs are smooth (Ianora \& Santella 1991, Belmonte \& Puce 1994, Belmonte et al. 1997, Chen \& Marcus 1997, Couch et al. 2001), which can easily be distinguished under the light microscope. Sometimes they have different colors (Cooley 1971, Walton 1985) or can be distinguished by the presence or absence of an extravitelline space (Lohner et al. 1990). In many calanoid copepods, however, it is difficult to distinguish 2 egg types only using a light microscope (Hairston \& Olds 1984, Chen \& Marcus 1997). The most common difference is in the shell structure, since there is generally a thick and multilayered shell around the embryo of diapause eggs, 
whereas subitaneous eggs have only a thin and singlelayered shell (Hairston \& Olds 1984, Santella \& Ianora 1990, Ianora \& Santella 1991, Couch et al. 2001).

However, physiological and biochemical studies of subitaneous and diapause eggs are noticeably lacking. Marcus \& Fuller (1986) observed a significant difference in the settling velocities and densities between subitaneous and diapause eggs. The density difference between the egg types may be an indication of intrinsic differences in the egg storage product, but the biochemical differences between subitaneous and diapause eggs have not been compared (Marcus 1996). Another obvious difference in the 2 egg types is the respiratory physiology. Oxygen consumption of subitaneous eggs of the marine copepod Pontella mediterranea increased steadily after spawning to reach maximum values about $25 \mathrm{~h}$ later, while oxygen metabolism of diapause eggs was greatly reduced during the refractory stage, with a resumption only prior to hatching (Romano et al. 1996).

In present paper, we investigated the density, sinking rate and biochemical composition of subitaneous and diapause eggs of Centropages tenuiremis. Significant differences were found in each of these.

\section{MATERIALS AND METHODS}

The calanoid copepod Centropages tenuiremis is widely distributed along the coast of China. In Xiamen Harbor, the occurrence of this species in the plankton is restricted to the winter and spring seasons. The species appears in the water column at the end of October and increases in number until an annual maximum density (80.2 ind. $\mathrm{m}^{-3}$ ) is reached in March (authors' unpubl. data). From October to April, only smooth subitaneous eggs are produced, most of which can hatch within 1 to $2 \mathrm{~d}$ at ambient temperatures. In May, the females begin to produce diapause eggs, which are spiny and do not hatch immediately (Li et al. 1989). After the annual maximum of $C$. tenuiremis in water, the planktonic population gradually decreases in size as water increases and completely disappears by the end of June (authors' unpubl. data).

Centropages tenuiremis were collected with a $240 \mu \mathrm{m}$ mesh plankton net from a station $\left(118^{\circ}\right.$ $\left.02.363^{\prime} \mathrm{E}, 24^{\circ} 26.778^{\prime} \mathrm{N}\right)$ in Xiamen Harbor, China. Samples were collected on multiple dates so that enough eggs were available. Samples for egg density measurement were collected in the spring of 2003. Samples for biochemical measurement were collected in the winter of 2002 and spring of 2003. The contents of the tow were diluted into $15 \mathrm{l}$ containers with ambient seawater and transported to the laboratory within $1 \mathrm{~h}$. Sea-surface temperature and salinity at the time and place of collection were measured with a thermometer (accuracy $0.5^{\circ} \mathrm{C}$ ) and refractometer (accuracy $0.1 \%$ ).

In the laboratory, adult Centropages tenuiremis females were transferred from the mixed plankton with wide-mouth pipettes into 2 egg incubation systems filled with seawater which had been filtered through a $5 \mu \mathrm{m}$ sieve. This filtering procedure removed any copepods eggs in the seawater. The incubation systems were self-made according to the design of Burkart \& Kleppel (1998), and the volume was enlarged so that enough eggs could be maintained. The copepods were offered a mixed diet (1:1) of Isochrysis galbana and Phaeodactylum tricornutum. Egg incubation systems were placed in a temperatureand light-controlled incubator $\left( \pm 1^{\circ} \mathrm{C}\right.$ of field temperature and the ambient outdoor light:dark photoperiod). C. tenuiremis were sampled at night and females were incubated overnight. The next morning freshly spawned eggs were collected for the investigations. Thus, eggs were 0 to $12 \mathrm{~h}$ old in the experiments. Identification of subitaneous and diapause eggs was based on their outer morphological differences. Diapause eggs of $C$. tenuiremis are spiny, while subitaneous eggs are smooth when viewed under the light microscope (Li et al. 1989).

Egg density was determined with a density-gradient centrifugation method using a sucrose solution. The density-gradient centrifugation method has been commonly used to investigate the density of copepods eggs (Marcus \& Fuller 1986, Miller \& Marcus 1994, Tang et al. 1998). The densities of the gradient were calculated as mass/volume; mass was determined with an electronic scale (accuracy $0.0001 \mathrm{~g}$ ). Five different densities $\left(1.06\right.$ to $1.18 \mathrm{~g} \mathrm{~cm}^{-3}$ for subitaneous eggs and 1.09 to $1.21 \mathrm{~g} \mathrm{~cm}^{-3}$ for diapause eggs at an increment of $0.03 \mathrm{~g} \mathrm{~cm}^{-3}$ ) were used. Solutions of the gradient were carefully transferred into $15 \mathrm{ml}$ centrifuge tubes (4 or 6 replicates) to make up 5 layers of increasing density, from top to bottom. At least 40 freshly spawned eggs were transferred onto the surface of the density gradient with a micropipette. A small amount of seawater was inevitably added to the gradient, but it never exceeded $1 \mathrm{ml}$. The tubes were centrifuged at $3000 \mathrm{rpm}$ $(950 \times g)$ for $30 \mathrm{~min}$. After centrifugation each layer was carefully pipetted out, from top to bottom. It was assumed that eggs that had settled in a particular layer had the same density as the others in that layer. All density measurements were made at room temperature $\left(25^{\circ} \mathrm{C}\right)$, and we did not control the osmotic potential of the density gradient since the change was very small (a 1\% change in egg density for a $100 \%$ change in ambient osmotic potential; Miller \& Marcus 1994).

Freshly spawned subitaneous and diapause Centropages tenuiremis eggs, 5500 of each, were collected and washed with distilled water twice. The samples 
were heat-dried in an electric oven at $60^{\circ} \mathrm{C}$ to a constant weight. Then the samples were kept in a desiccator before being weighed with an electronic scale (accuracy $0.00001 \mathrm{~g}$ ). The total protein content of the eggs was determined by the method of Bradford (1976), with bovine serum albumin as the standard. Freshly spawned subitaneous and diapause eggs, 1800 of each, were used. The total lipid of freshly spawned subitaneous and diapause eggs, 5500 of each, was extracted following a modified procedure of Folch et al. (1957) using chloroform-methanol (2:1) and esterified with a mixture of $1 \% \mathrm{H}_{2} \mathrm{SO}_{4}$ in methanol. The total carbohydrate content of 2500 freshly spawned subitaneous and diapause eggs, 2500 of each was determined by means of the phenol-sulfuric acid reaction (Dubois et al. 1956) using glucose as a standard. The amino acid of the eggs was extracted for $24 \mathrm{~h}$ in $6 \mathrm{~mol}$ $\mathrm{HCl}$. After centrifugation $(20 \mathrm{~min}$ at $15000 \mathrm{rpm}$ $[5000 \times g]$ ) the supernatants of 1800 freshly spawned eggs were analyzed in a Hitachi L-8500 Amino Acid analyzer. Each test had 2 replicates. The differences between subitaneous and diapause eggs were compared using Student's $t$-test.

\section{RESULTS}

The densities of subitaneous and diapause eggs of Centropages tenuiremis are listed in Table 1. The mean density of subitaneous eggs was $1.1176 \mathrm{~g} \mathrm{~cm}^{-3}$ with a $\mathrm{SD}$ of $0.0057 \mathrm{~g} \mathrm{~cm}^{-3}$, while the mean density of diapause eggs was $1.1481 \mathrm{~g} \mathrm{~cm}^{-3}$ with a SD of $0.0101 \mathrm{~g}$ $\mathrm{cm}^{-3}$. The frequency distributions of densities of 1364 subitaneous and 824 diapause eggs are shown in Fig. 1. The mean density of diapause eggs was $2.73 \%$ higher than that of subitaneous eggs. Despite some overlap, the result of the $t$-test indicated that there was a significant $(p<0.01)$ difference between the densities of subitaneous and diapause eggs.

Egg sinking rates were calculated with Stokes' law. Seawater density and kinematic viscosity for Stokes'

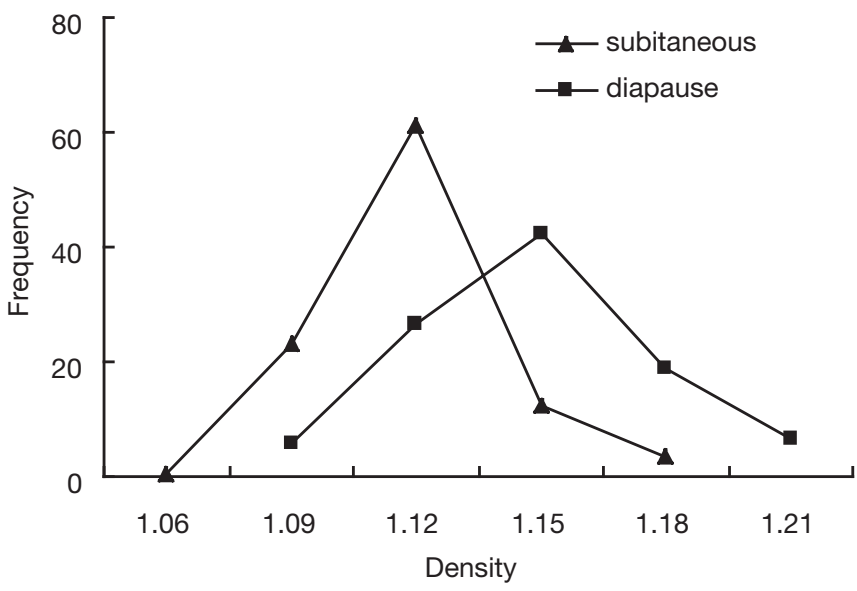

Fig. 1. Centropages tenuiremis. Frequency distribution of subitaneous and diapause egg densities $\left(\mathrm{g} \mathrm{cm}^{-3}\right)$

law were estimated from water temperatures and salinity (Sverdrup et al. 1942). Fifty subitaneous and diapause eggs each, used to determine the mean egg diameter, were collected from the same field population on 31 May 2003. The diameter was determined with a microscope at $160 \times$ using an ocular micrometer. The mean diameters of subitaneous and diapause eggs were used in Stokes' law. The mean diameter of subitaneous eggs was $77.90 \mu \mathrm{m}$ with a SD of $3.85 \mu \mathrm{m}$, while the mean diameter (without spines) of diapause eggs was $79.69 \mu \mathrm{m}$ with a SD of $3.40 \mu \mathrm{m}$. The result of the $t$-test indicated that there was a significant $(\mathrm{p}<$ 0.05) difference between subitaneous and diapause eggs of Centropages tenuiremis. The mean diameter of diapause eggs was $2.30 \%$ larger than that of subitaneous eggs.

The sinking rates of Centropages tenuiremis eggs from each collection were calculated with Stokes' law (Table 1). The sinking rate of subitaneous eggs ranged from 0.0252 to $0.0269 \mathrm{~cm} \mathrm{~s}^{-1}$, while the sinking rate of diapause eggs ranged from 0.0337 to $0.0385 \mathrm{~cm} \mathrm{~s}^{-1}$, i.e. $37.97 \%$ higher than that of subitaneous eggs. The results of the $t$-test indicated that there was a significant $(\mathrm{p}<$

Table 1. Centropages tenuiremis. Density and sinking rates of subitaneous and diapause eggs

\begin{tabular}{|c|c|c|c|c|c|c|c|c|}
\hline & Date & $\begin{array}{c}\text { Temperature } \\
\left({ }^{\circ} \mathrm{C}\right)\end{array}$ & Salinity & Replicates & Total no. & $\begin{array}{l}\text { Egg density } \\
\qquad\left(\mathrm{g} \mathrm{cm}^{-3}\right)\end{array}$ & $\mathrm{SD}$ & $\begin{array}{l}\text { Sinking rate } \\
\left(\mathrm{cm} \mathrm{s}^{-1}\right)\end{array}$ \\
\hline \multirow[t]{4}{*}{ Subitaneous } & 2 May 2003 & 23.5 & 28.8 & 4 & 375 & 1.1191 & 0.0065 & 0.0269 \\
\hline & 13 May 2003 & 25.0 & 28.2 & 6 & 270 & 1.1148 & 0.0027 & 0.0260 \\
\hline & 20 May 2003 & 24.5 & 26.8 & 6 & 431 & 1.1233 & 0.0035 & 0.0285 \\
\hline & 25 May 2003 & 25.5 & 28.0 & 6 & 288 & 1.1115 & 0.0022 & 0.0252 \\
\hline \multirow[t]{4}{*}{ Diapause } & 31 May 2003 & 26.0 & 27.9 & 6 & 200 & 1.1474 & 0.0064 & 0.0365 \\
\hline & 2 Jun 2003 & 26.5 & 28.2 & 6 & 185 & 1.1543 & 0.0053 & 0.0385 \\
\hline & 8 Jun 2003 & 26.5 & 27.6 & 6 & 184 & 1.1373 & 0.0095 & 0.0337 \\
\hline & 10 Jun 2003 & 26.5 & 27.5 & 6 & 255 & 1.1535 & 0.0092 & 0.0383 \\
\hline
\end{tabular}


0.01) difference between subitaneous and diapause eggs.

The dry weight and biochemical composition of Centropages tenuiremis are shown in Fig. 2. The dry weight of subitaneous $C$. tenuiremis eggs was $117.7 \mathrm{ng} \mathrm{egg}^{-1}$ with a SD of $9.45 \mathrm{ng}$ $\mathrm{egg}^{-1}$, while the dry weight of diapause eggs was $165.0 \mathrm{ng} \mathrm{egg}^{-1}$ with a SD of $3.40 \mathrm{ng} \mathrm{egg}^{-1}, 39.8 \%$ higher than that of subitaneous eggs. The lipid, protein and carbohydrate contents of subitaneous eggs were 32.9, 59.1 and $9.4 \mathrm{ng}$ $\mathrm{egg}^{-1}$, respectively, while those of diapause eggs were 57.1, 81.2 and 11.2 ng $\mathrm{egg}^{-1}$. Both protein and lipid generally comprised the major organic fractions of C. tenuire-mi eggs. The organic constituents of the diapause eggs were all noticeably higher than those of subitaneous eggs: $73.6 \%$ for lipids, $37.4 \%$ for protein and $19.1 \%$ for carbohydrate. The result of the $t$-test showed that the difference between subitaneous and diapause eggs was significant for dry weight $(\mathrm{p}<0.01)$.

Total amino acid (AA) content was $71.478 \mathrm{ng} \mathrm{egg}^{-1}$ for subitaneous eggs and $97.078 \mathrm{ng} \mathrm{egg}^{-1}$ for diapause eggs of Centropages tenuiremis (Table 2). Total AA made up $60.7 \%$ of the subitaneous egg dry mass and $58.8 \%$ of the diapause egg dry mass. Total AA content in diapause eggs was significantly higher than in subitaneous eggs $(p<0.05)$. Glutamic acid and aspartic acid followed by valine and lysine dominated among the total AAs in C. tenuiremis subitaneous and diapause eggs. The levels of aspartic acid, glutamic acid, glycine, methionine, isoleucine, leucine, norleucine,

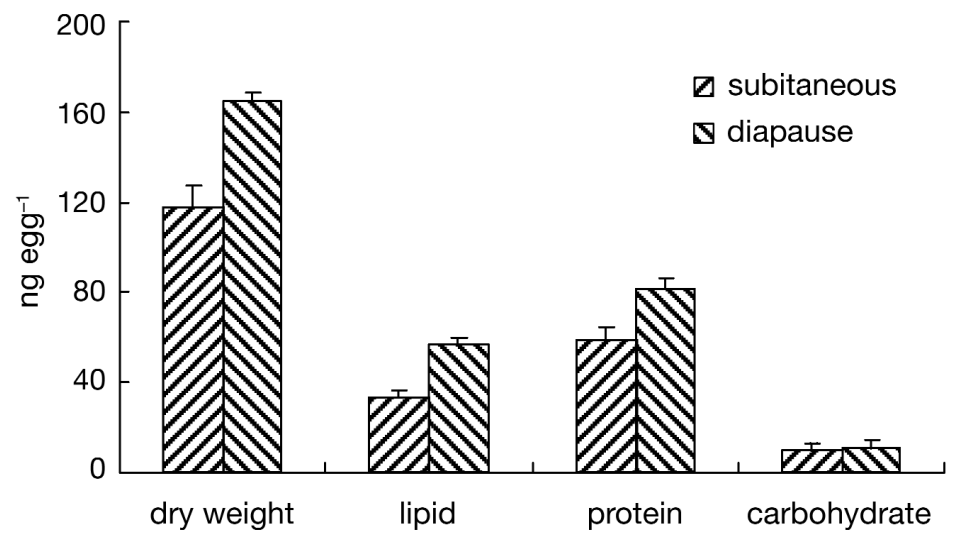

Fig. 2. Centropages tenuiremis. Dry weight and biochemical composition of subitaneous and diapause eggs. Error bars are $+1 \mathrm{SD}$ from the mean lysine, ammonium chloride, and arginine were obviously higher in diapause eggs than in subitaneous eggs, while differences in other AAs were not significant (Table 2).

\section{DISCUSSION}

Although most attention has been paid to morphological differences in past research, our present investigation showed that there were significant physiological and biochemical differences between Centropages tenuiremis subitaneous and diapause eggs. The difference in the density of subitaneous and diapause eggs was small $(2.73 \%)$ but significant. It was similar to that observed in Labidocera aestiva by Marcus \& Fuller (1986). This difference could mainly be due to differences in dry weight and biochemical composition. In order to ensure long-term survival, diapause eggs need a complex egg structure which is capable of withstanding an unfavorable environment and enough storage products to maintain metabolism. Therefore, it is not surprising that the weight of C. tenuiremis diapause eggs was $40.2 \%$ higher than that of subitaneous eggs.

The fall velocity of Centropages tenuiremis diapause eggs is higher than that of subitaneous eggs, which suggests that the diapause eggs would rapidly settle to the sea floor. The significance of fast settlement is that it could reduce the potential predation pressure in the 
water column (although some studies showed that copepod diapause eggs could pass through predator guts; Marcus 1984, Parker et al. 1996). Compared to the fast settlement of diapause eggs, the sinking rate of C. tenuiremis subitaneous eggs was relatively slow, which means that they would stay in the water column for a long period and could hatch before sinking out of the water column. However, the sinking velocity of the subitaneous eggs was $0.0266 \mathrm{~cm} \mathrm{~s}^{-1}$, which indicates that eggs could reach a depth of $20 \mathrm{~m}$ within $24 \mathrm{~h}$. The egg hatching time of the $C$. tenuiremis subitaneous eggs varied greatly with the water temperature, which ranged from 23 to $83 \mathrm{~h}$ in Xiamen Bay (authors' unpubl. data). The water depth of Xiamen Bay ranges from 6 to $25 \mathrm{~m}$. A comparison of the egg deposition time and egg hatching time suggests that $C$. tenuiremis subitaneous eggs would settle to the bottom prior to hatching in a shallow area, even though they have a high potential to hatch before reaching the seabed.

The difference in the fall velocity of Centropages tenuiremis subitaneous and diapause eggs was $37.97 \%$. Marcus \& Fuller (1986) reported that the difference in the average fall velocities of Labidocera aestiva subitaneous and diapause eggs was approx. $25 \%$. It is still unknown whether or not this difference is so large that the distribution of the 2 egg types on the sea floor is markedly different. The effect of the spines of C. tenuiremis diapause eggs was neglected when we calculated the sinking rates with Stokes' law. The spiny covering most likely will delay sinking because it increases the bearing surface (Belmonte at al. 1997). Spines, however, can also promote sinking: the majority of bloom-forming diatoms, in fact, have simple or even barbed protuberances with which they become entangled, forming aggregations. This enhances their sinking rates, removing them from the nutrient depleted area where the bloom occurred (Smetacek 1985, Belmonte et al. 1997). An alternative method to determine the sinking rates of copepod eggs is to directly record the sinking of eggs in a settling chamber (Marcus \& Fuller 1986). This method is simple and may reflect the effect of spines on the sinking rates of diapause eggs. However, the diameters of subitaneous and diapause eggs were, respectively, 77.90 and $79.69 \mu \mathrm{m}$. It is almost impossible to see $C$. tenuiremis eggs with the naked eye due to their small size. The egg sinking rates presented here are the theoretical rates for a laminar environment (Tang et al. 1998). The actual sinking rates of eggs in the field would be influenced by vertical turbulent motion in the water. Additional information regarding the sinking rate, turbulent motion, and the time and depth of spawning events is crucial for a better understanding of the depositional dynamics of copepod eggs in the field, and will improve our insight into the planktonic copepod population.

Copepod diapause eggs have been shown to be capable of resting for very long periods of time, i.e. decades or even centuries (Marcus et al. 1994, Hairston et al. 1995). So it is not surprising that a complex egg structure capable of withstanding unfavorable environmental conditions and a large storage capacity are necessary for these eggs to survive for such long periods of time, which may result in the high dry weight of diapause eggs compared to that of subitaneous eggs. One of the morphological differences between diapause and subitaneous eggs of copepods is the shell structure, diapause eggs generally having a thick, multilayered shell, while subitaneous eggs have a thin, single-layered shell (Hairston \& Olds 1984, Santella \& Ianora 1990, Couch et al. 2001). The presence of the chorion or external layer composed of lipoprotein impregnated with chitin and hematin was the major reason for the high protein content of diapause cysts of Artemia (García-Ortega et al. 1998). Similarly the high protein content of diapause eggs of Centropages tenuiremis could be due to the thick, multilayered shell.

Although proteins are the main component of eggs in marine invertebrates, lipids play an important role in the embryonic metabolism (Holland 1978). They represent the most important energy source and cover at least $60 \%$ of the total energy expenditure of the developing crustacean embryo (Amsler \& George 1984). The most obvious manifestation of the diapausing copepodid stages in species of Calanus is the large accumulation of lipids before and during dormancy (Conover 1988, Sargent \& Falk-Petersen 1988). The lipid and protein contents of diapause eggs of Centropages tenuiremis were noticeabley higher than those of subitaneous eggs, which may indicate that they would be used as metabolic energy reservers during the period of resting. However, one complication is that since diapause eggs typically occur in anoxic sediments lipids might not be useful as a storage compound because oxygen is required for their metabolism (Marcus 1996). After spawning from the female, diapause eggs settle to the seabed and are buried under sediment. They stop their development and remain dormant due to the lack of oxygen (Kasahara et al. 1975). Hatching is inhibited until they return to the water column due to physical and biological resuspension. The respiration curve of diapause eggs of Pontella mediterranea characteristically followed the typical U-shaped pattern described for insect diapause (Romano et al. 1996). During the pre-diapause and post-diapause period, diapause eggs had high rates of $\mathrm{O}_{2}$ uptake, while $\mathrm{O}_{2}$ consumption dropped to a low level during diapause. The lipids in C. tenuiremis dia- 
pause eggs might be used as energy fuel to meet the higher energy requirements during the pre-diapause and post-diapause periods, when oxygen is available. During the period of diapause, proteins might be used as a source of energy to ensure egg survival, since lipids might not be used in anoxic conditions. Warner et al. (1972) showed that yolk platelets in diapause cysts of Artemia contained about $75 \%$ of their mass as protein, and that this decreased during the period of diapause. Romano et al. (1996) suggested that there was a gradual decrease in the yolks of $P$. mediterranea eggs during the period of diapause. We, therefore, think that proteins and lipids might be used as a source of energy at different stages, which may explain why the diapause eggs have high levels of proteins and lipids compared to the subitaneous eggs of $C$. tenuiremis.

Total AAs constitued $60.7 \%$ of the subitaneous egg dry mass and $58.8 \%$ of the diapause egg dry mass in Centropages tenuiremis. AAs are predominantly used as metabolic fuel, and also utilized for protein synthesis. Marine fish eggs support 50 to $70 \%$ of their energy dissipation via catabolism of AAs (Rønnestad et al. 1999). In C. tenuiremis, total AA levels in diapause eggs were significantly higher than those in subitaneous eggs, which may indicate that AAs would be produced as an energy fuel to ensure survival over long periods of time. Glutamic acid and aspartic acid followed by valine and lysine dominated among the total AAs in subitaneous and diapause eggs of $C$. tenuiremis. Our results are comparable to the AA composition of Euterpina acutifrons eggs, in which the dominate essential AAs were glutamic acid, arginine, lysine, and aspartic acid (Guisande et al. 2000). Generally, the individual AA levels in diapause eggs were higher than those in subitaneous eggs of $C$. tenuiremis. It is known that glycine, alanine, praline, and taurine have no significant effect on enzymatic activity according to data on catalytic rates or the influence of Michaelis constant $\left(K_{\mathrm{m}}\right)$ values (Yancey et al. 1982). However, arginine and lysine do have an influence on the enzymatic catalytic function (Bowlus \& Somero 1979). The high levels of arginine and lysine in diapause eggs of $C$. tenuiremis might help to maintain a necessary level of metabolism during the long diapause period. Taurine is an almost ideal osmolyte and is present as a major osmolyte in many animal phyla (Huxtable 1992). Taurine could originate from the catabolism of methionine and cysteine (Allen \& Garrett 1971). In the current study the difference in the taurine content of subitaneous and diapause eggs was not significant. However, the methionine content in diapause eggs was significantly greater than that in subitaneous eggs. During the long diapause period methionie might be catabolized into taurine, which could regu- late the osmotic equilibrium of diapause eggs in order to enable them to withstand unfavorable conditions. Some research showed that the essential AA composition of copepod eggs probably varied according to the food source (Guisande et al. 1999, 2000). Thus, the difference in the AA composition of subitaneous and diapause eggs might have been influenced by the natural seston, since the $C$. tenuiremis adults were kept on the lab diet for about $12 \mathrm{~h}$ before eggs were collected.

Acknowledgements. This work was supported by the National Science Foundation of China under Grant No. 40076034. The experiment complied with the laws of the PR China.

\section{LITERATURE CITED}

Allen JA, Garrett MR (1971) Taurine in marine invertebrates. Adv Mar Biol 9:205-253

Amsler MO, George RY (1984) Seasonal variation in the biochemical composition of the embryos of Callinectes sapidus Rathbun. J Crustac Biol 4:546-553

Bell EM, Weithoff G, (2003) Benthic recruitment of zooplankton in an acidic lake. J Exp Mar Biol Ecol 285/286:205-219

Belmonte G, Puce M (1994) Morphological aspects of subitaneous and resting eggs from Acartia josephinae (Calanoida). Hydrobiologia 292/293:131-135

Belmonte G, Miglietta A, Rubino F, Boero F (1997) Morphological convergence of resting stages of planktonic organisms: a review. Hydrobiologia 355:159-165

Boero F, Belmonte G, Fanelli G, Piraino S, Rubino F (1996) The continuity of living matter and the discontinuities of its constituents: Do plankton and benthos really exist? Trends Ecol Evol 11:177-180

Bowlus RD, Somero GN (1979) Solute compatibility with enzyme function and structure: rationales for the selection of osmotic agents and end-products of anaerobic metabolism in marine invertebrates. J Exp Zool 208:137-152

Bradford M (1976) A rapid and sensitive method for the quantification of microgram quantities of protein utilizing the principle of proteins dye binding. Anal Biochem 72: 248-254

Burkart CA, Kleppel GS (1998) A new incubation system for the measurement of copepod egg production and egg hatching success in the field. J Exp Mar Biol Ecol 221: 89-97

Chen F, Marcus NH (1997) Subitaneous, diapause, and delayed-hatching eggs of planktonic copepods from the northern Gulf of Mexico: morphology and hatching success. Mar Biol 127:587-597

Conover RJ (1988) Comparative life histories in the genera Calanus and Neocalanus in high latitudes of the northern Hemisphere. Hydrobiologia 167/168:127-142

Cooley JM (1971) The effect of temperature on the development of resting eggs of Diaptomus oregonensis Lilljeborg (Copepoda: Calanoida). Limnol Oceanogr 16:921-926

Couch KM, Downes M, Burns CW (2001) Morphological differences between subitaneous and diapause eggs of Boeckella triarticulata (Copepoda: Calanoida). Freshw Biol 46:925-933

Dubois M, Gilles KA, Hamilton JK, Rebers PA, Smith F (1956) Colorimetric method for determination of sugars and related substances. Anal Chem 28:350-356 
Folch J, Lees M, Stanley GS (1957) A simple method for the isolation and purification of total lipids from animal tissues. J Biol Chem 226:497-509

García-Ortega A, Verreth JAJ, Coutteau P, Segner H, Huisman EA, Sorgeloos P (1998) Biochemical and enzymatic characterization of decapsulated cysts and nauplii of the brine shrimp Artemia at different developmental stages. Aquiculture 161:501-514

Grice GD, Marcus NH (1981) Dormant eggs of marine copepods. Oceanogr Mar Biol Annu Rev 19:125-140

Guisande C, Maneiro I, Riveiro I (1999) Homeostasis in the essential amino acid composition of the marine copepod Euterpina acutifrons. Limnol Oceanogr 44:691-696

Guisande C, Riveiro I, Maneiro I (2000) Comparisons among the amino acid composition of females, eggs and food to determine the relative importance of food quantity and food quality to copepod reproduction. Mar Ecol Prog Ser 202:135-142

Hairston NG Jr, Olds EJ (1984) Population differences in the timing of diapause: adaptation in a spatially heterogenous environment. Oecologia 61:42-48

Hairston NG Jr, van Brunt RA, Kearns CM, Engstrom DR (1995) Age and survivorship of diapausing eggs in a sediment egg bank. Ecology 76:1706-1711

Hairston NG Jr, Hansen AM, Schaffiner WR (2000) The effect of diapause emergence on the seasonal dy namics of a zooplankton assemblage. Freshw Biol 45:133-145

Holland DL (1978) Lipid reserves and energy metabolism in the larvae of benthic marine invertebrates. In: Malins DC, Sargent JR (eds) Biochemical and biophysical perspectives in marine biology. Academic Press, London, p 85-123

Huxtable RJ (1992) Physiological actions of taurine. Physiol Rev 72:101-159

Ianora A, Santella L (1991) Diapause embryos in the neustonic copepod Anomalocera patersoni. Mar Biol 108:387-394

Kasahara S, Uye S, Onbe T (1975) Calanoid copepod eggs in sea-bottom muds. II. Seasonal cycles of abundance in the populations of several species of copepods and their eggs in the Inland Sea of Japan. Mar Biol 31:25-29

Li SJ, Chen F, Wang GZ (1989) Studies on the feature of eggs and their hatching rates of some planktonic copepods in Xiamen waters. J Xiamen Univ (Nat Sci) 28:538-543 (in Chinese with English abstract)

Lohner L, Hairston NG Jr, Schaffner W (1990) A method for distinguishing subitaneous and diapausing eggs in preserved samples of the calanoid copepod genus Diaptomus. Limnol Oceanogr 35:763-767

Marcus NH (1984) Recruitment of copepod nauplii into the plankton: importance of diapause eggs and benthic processes. Mar Ecol Prog Ser 15:47-54

Marcus NH (1996) Ecological and evolutionary significance of

Editorial responsibility: Otto Kinne (Editor-in-Chief), Oldendorf/Luhe, Germany resting eggs in marine copepods: past, present, and future studies. Hydrobiologia 320:141-152

Marcus NH, Fuller CM (1986) Subitaneous and diapause eggs of Labidocera aestiva Wheeler (Copepoda: Calanoida): differences in fall velocity and density. J Exp Mar Biol Ecol 99:247-256

Marcus NH, Lutz RV, Burnett W, Cable P (1994) Age, viability, and vertical distribution of zooplankton resting eggs from an anoxic basin: evidence of an egg bank. Limnol Oceanogr 39:154-158

Miller DD, Marcus NH (1994) The effects of salinity and temperature on the density and sinking velocity of eggs of the calanoid coepod Acartia tonsa Dana. J Exp Mar Biol Ecol 179:235-252

Parker BR, Wilhelm FM, Schindler DW (1996) Recovery of Hesperodiaptomus population from diapausing eggs following elimination by stocked salmonids. Can J Zool 74: 1292-1297

Romano G, Ianora A, Santella L, Miralto A (1996) Rrespiratory metabolism during embryonic subitaneous and diapause development in Pontella mediterranea (Crustacean, Copepoda). J Comp Physiol B 166:157-163

Rønnestad I, Thorsen A, Finn RN (1999) Fish larval nutrition: a review of recent advances in the roles of amino acids. Aquaculture 177:201-216

Santella L, Ianora A (1990) Subitaneous and diapause eggs in Mediterranean populations of Pontella mediterranea (Copepoda: Calanoida): a morphological study. Mar Biol 105:83-90

Sargent JR, Falk-Petersen S (1988) The lipid biochemistry of calanoid copepods. Hydrobiologia 167/168:101-114

Smetacek VS (1985) Role of sinking in diatom life-history cycles: ecological, evolutionary and geological significance. Mar Biol 84:239-251

Sverdrup HU, Johnson MW, Fleming RH (1942) The oceans: their physics, chemistry and general biology. Prentice Hall, Englewood Cliffs, NJ

Tang KW, Dam HG, Feinberg LR (1998) The relative importance of egg production rate, hatching success, hatching duration and egg sinking in population recruitment of 2 species of marine copepods. J Plankton Res 20:1971-1987

Walton WE (1985) Factors regulating the reproductive phenology of Onychodiaptomus birgei (Copepoda: Calanoida). Limnol Oceanogr 30:167-179

Warner AH, Puodziukas JG, Finamore FJ (1972) Yolk platelets in brine shrimp embryos. Site of biosynthesis and storage of the diguanosine nucleotides. Explor Cell Res 70: 365-375

Yancey PH, Clark ME, Hand SC, Bowlus RD, Somero GN (1982) Living with water stress: evolution of osmolyte systems. Science 217:1214-1222

Submitted: November 10, 2003; Accepted: November 11, 2004 Proofs received from author(s): January 31, 2005 